\title{
Nodular pretibial myxoedema after treatment of Graves disease with radioactive iodine ablation therapy
}

\author{
Deepa Ponnusamy, Rajasree Pai Ramachandra Pai
}

Department of Endocrinology and Metabolism, Texas A\&M, Temple, Texas, USA

\section{Correspondence to}

Dr Rajasree Pai

Ramachandra Pai,

Drrajashree.pai@gmail.com

Accepted 1 March 2014

\section{DESCRIPTION}

A 45-year-old African-American woman presented with a 2-month history of bulging eyes, neck swelling, increased appetite and oligomenorrhea. On examination, she had fine hand tremors and bilateral proptosis with lid lag. The thyroid gland was diffusely enlarged. Laboratory test revealed suppressed thyrotropin-stimulating hormone and elevated free thyroxine levels at $7.4 \mathrm{ng} / \mathrm{dL}$ (normal $0.76-1.46 \mathrm{ng} / \mathrm{dL}$ ). She was diagnosed with Graves disease and treated with $15.3 \mathrm{mCi}$ of radioactive iodine therapy. She had normalisation of thyroid function tests after the treatment.

Eight months later, she noted multiple, nontender, raised nodular lesions in her shins bilaterally (figure 1A). Differential diagnosis included chronic erythema nodosum and nodular form of pretibial myxoedema. Biopsy was performed and cytopathology revealed marked dermal mucin, consistent with pretibial myxoedema (figure 1B). She was prescribed clobetasol ointment for her lesions.

Dermopathy occurs in less than $5 \%$ of patients with Graves disease. Typical lesion is diffuse, non-pitting oedema with 'orange-skin' appearance involving the shins. Nodular lesions are rare, in less than $10 \%$ of patients with pretibial myxoedema.

This case emphasises the atypical signs of Graves disease and changes that can occur in the skin even after Graves disease has been successfully treated. Physicians following patients with Graves disease after definitive management of the same should be aware of this rare form of thyroid dermopathy.

\section{Learning points}

Nodular pretibial myxoedema is a rare form of thyroid dermopathy in patients with Graves disease.

- Nodular pretibial myxoedema can occur in patients after radioactive iodine therapy.

- It can present as nodular lesions in front of the shins mimicking erythema nodosum in appearance and can be treated with topical steroids if symptomatic.
To cite: Ponnusamy $\mathrm{D}$ Ramachandra Pai RP. BMJ Case Rep Published online: [please include Day Month Year] doi:10.1136/bcr-2013202530
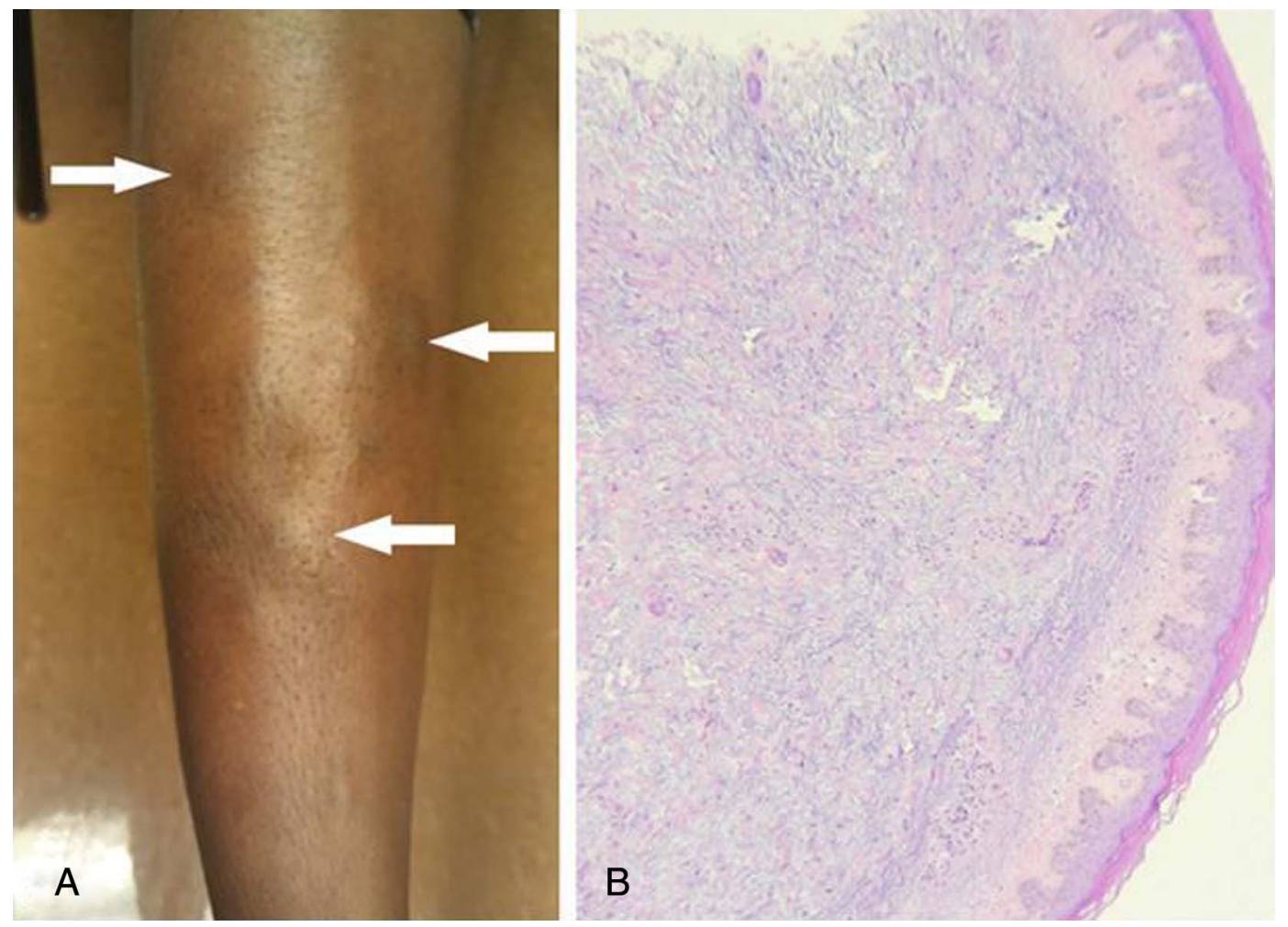

Figure 1 (A) Photograph of lower extremity showing raised nodular lesions of the shin. (B) Histopathology image demonstrating dermal mucin. 
Acknowledgements The authors would like to thank Dr Lisa Lopez MD, Department of Pathology, Scott and White Hospital, Texas for providing the photomicrograph.

Competing interests None.
Patient consent Obtained.

Provenance and peer review Not commissioned; externally peer reviewed.

Copyright 2014 BMJ Publishing Group. All rights reserved. For permission to reuse any of this content visit http://group.bmj.com/group/rights-licensing/permissions.

BMJ Case Report Fellows may re-use this article for personal use and teaching without any further permission.

Become a Fellow of BMJ Case Reports today and you can:

- Submit as many cases as you like

- Enjoy fast sympathetic peer review and rapid publication of accepted articles

- Access all the published articles

- Re-use any of the published material for personal use and teaching without further permission

For information on Institutional Fellowships contact consortiasales@bmjgroup.com

Visit casereports.bmj.com for more articles like this and to become a Fellow 